\title{
THE BOOK OF CHILAM BALAM OF CHUMAYEL
}

\author{
INTRODUCTION (Excerpt) \\ http://www.sacred-texts.com/nam/maya/cbc/cbc05.htm
}

The Books of Chilam Balam are the sacred books of the Maya of Yucatan and were named after their last and greatest prophet. Chilam, or chilan, was his title which means that he was the mouth-piece or interpreter of the gods. Balam means jaguar, but it is also a common family name in Yucatan, so the title of the present work could well be translated as the Book of the Prophet Balam.

During a large part of the colonial period, and even down into the Nineteenth Century, many of the towns and villages of northern Yucatan possessed Books of Chilam Balam, and this designation was supplemented by the name of the town to which the book belonged. Thus the Book of Chilam Balam of Chumayel is named for a village in the District of Tekax, a short distance northwest of the well-known town of Teabo.

This Prophet Balam lived during the last decades of the Fifteenth Century and probably the first of the Sixteenth Century 1 and foretold the coming of strangers from the east who would establish a new religion. The prompt fulfilment of this prediction so enhanced his reputation as a seer that in later times he was considered the authority for many other prophecies which had been uttered long before his time. Inasmuch as prophecies were the most prominent feature of many of the older books of this sort, it was natural to name them after the famous soothsayer.

The Books of Chilam Balam were written in the Maya language but in the European script which the early missionaries adapted to express such sounds as were not found in Spanish. Each book is a small library in itself and contains a considerable variety of subject material. Besides the prophecies we find brief chronicles, fragmentary historical narratives, rituals, native catechisms, mythological accounts of the creation of the world, almanacs and medical treatises. Many such passages were no doubt originally transcribed from older hieroglyphic manuscripts, some of which were still in existence in northern Yucatan as late as the close of the Seventeenth Century 2. As time went on, more and more European material was added to the native Maya lore. In some of the books not only do we find the ritual of a religion which is a

\section{p. 4}

mixture of the old faith with Christianity, but there are also translations into Maya of Spanish religious tracts and astrological treatises, as well as notes of events which occurred during the colonial period. In two of these books we even find part of a Spanish romance translated into Maya. 1

The ability of the Maya to write their own language in European script was due to the educational policy of the Spanish missionaries. Although at first they rather admired the Maya for having a graphic system of their own, they were determined to destroy the old manuscripts and eradicate all knowledge of the glyphs from the minds of their converts. The Indians had a great reverence for their hieroglyphic writing which was permeated with the symbols of their old religion, and the friars felt that if they could wipe out this knowledge and substitute for it the European system of writing, it would be an effective means for the complete Christianization of the native population. This should be the easier, since the knowledge of hieroglyphic writing was confined to the priesthood and certain members of the nobility. Diego de Landa, afterward bishop of Yucatan, burned twenty-seven hieroglyphic manuscripts at the famous auto de fe in Mani in 1562, and although many of the Spaniards severely criticized him for this, there is little doubt that other missionaries followed his example whenever they had the opportunity. 


\section{CHAPTER X}

\section{(THE CREATION OF THE WORLD) 2}

http://www.sacred-texts.com/nam/maya/cbc/cbc15.htm

It is most necessary to believe this. These are the precious stones which our Lord, the Father, has abandoned. ${ }_{3}$ This was his first repast, this balché, 4 with which we, the ruling men revere him here. Very rightly s they worshipped as true gods these precious stones, $\underline{6}$ when the true God was established, our Lord God, the Lord of heaven and earth, the true God. Nevertheless, the first gods were perishable gods. Their worship came to its inevitable end. They lost their efficacy by the benediction of the Lord of Heaven, after the redemption of the world was accomplished, after the resurrection of the true God, the true Dios, when he blessed heaven and earth. Then was your worship abolished, Maya men. Turn away your hearts from your $<$ old $>$ religion.

$<$ This is $>$ the history of the world in those times, because it has been written down, because the time has not yet ended for making these books, these many explanations, so that Maya men may be asked if they know how they were born here in this country, when the land was founded.

p. 99

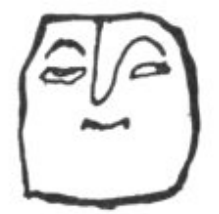

FIG. 23-- The lord of the katun (Chumayel MS.).
The face is darkened or blurred. The face is darkened or blurred. with wood and stone. Then Oxlahun-ti-ku / was seized, his head was wounded, his face was buffeted, he was spit upon, and he was <thrown $>$ on his back as well. After that he was despoiled of his insignia $\underline{\underline{6}}$ and his smut. $\underline{\underline{ }}$ Then shoots of the yaxum tree $\underline{\underline{s}}$ were taken. Also Lima beans were taken with crumbled tubercles, hearts of small squash-seeds, large squash-seeds $\underline{9}$ and beans, all crushed. He wrapped up the seeds <composing > this first Bolon çacab, 10 and went to the thirteenth heaven. 11 Then a mass of maize-dough with the tips of corn-cobs remained here on earth. Then its heart departed because of Oxlahun-ti-ku, but they did not know the heart of the tubercle was gone. After that the fatherless ones, the miserable ones, and those without husbands were all pierced through; 12 they were alive though they had no hearts. Then they were buried in the sands, in the sea.

There would be a sudden rush of water when the theft of the insignia ${ }_{13}<$ of Oxlahun-ti-ku> occurred. Then the sky would fall, it would fall down

p. 100

upon the earth, when the four gods, the four Bacabs, were set up, who brought about the destruction of the world. 1 Then, after the destruction of the world was completed, they placed $<$ a tree $>\underline{2}$ to set up in its order 
the yellow cock oriole. Then the white tree of abundance was set up. A pillar of the sky was set up, a sign of the destruction of the world; that was the white tree of abundance in the north. Then the black tree of abundance was set up <in

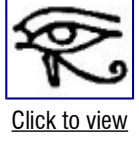

FIG. 24--Lahun Chaan, associated with the planet Venus (Dresden Codex, p. 47).

the west ${ }_{\underline{3}}$ for the black-breasted piçoy ${ }_{4}$ to sit upon. Then the yellow tree of abundance was set up $<$ in the south $>, \underline{5}$ as a symbol of the destruction of the world, for the yellow-breasted piçoy to sit upon, for the yellow cock oriole to sit upon, the yellow timid mut. Then the green tree of abundance was set up in the center $<$ of the world $>$ as a record of the destruction of the world.

p. 101

The plate ${ }_{1}$ of another katun was set up and fixed in its place by the messengers of their lord. The red Piltec was set at the east of the world to conduct people to his lord. The white Piltec was set at the north of the world to conduct people / to his lord. Lahun Chaan 2 was set $<$ at the west $>$ to bring things to his lord. The yellow Piltec was set <at the south $>$ to bring things to his lord. But it was <over $>$ the whole p. $44 \mathrm{C}$ world that Ah Uuc Cheknal $\underline{\underline{ }}$ was set up. He came from the seventh stratum of the earth, when he came to fecundate Itzam-kab-ain, 4 when he came with the vitality of the angle between earth <and > heaven. $\underline{5}$ They moved among the four lights, $\underline{6}$ among the four layers of the stars. The world was not lighted; there was neither day nor night nor moon. Then they perceived that the world was being created. Then creation dawned upon the world. During the creation thirteen infinite

p. 102

series $_{1}<$ added $>$ to seven was the count of the creation of the world. Then a new world dawned for them.

The two-day throne was declared, the three-day throne. Then began the weeping of Oxlahun-ti-ku. They wept in this reign. The reign became red; the mat became red; the first tree of the world was rooted fast. 2 The entire world was proclaimed by Uuc-yol-zip; $\underline{3}$ but it was not at the time of this reign that Bolon-ti-ku-wept. Then came the counting of the mat in its order. ${ }_{4}$ Red was the mat on which Bolon-ti-ku sat. His buttock is sharply rounded, $\underline{5}$ as he sits on his mat. Then descended greed from the heart of the sky, greed for power, greed for rule.

Then the red foundation was established; the white foundation of the ruler was established; the black foundation was established; the yellow foundation was established. $\underline{6}$ Then the Red Ruler was set up, he who was raised ${ }_{\underline{I}}$ upon the mat, raised upon the throne. The White Ruler was set up, he who was raised upon the mat, raised upon the throne. The Black Ruler was set up, he who was raised upon the mat, raised upon the throne. The Yellow Ruler was set up, he who was raised upon the mat, raised upon the throne. $\underline{8}$ 
[paragraph continues] As a god, it is said; 1 whether or not gods, their bread is lacking, their water is lacking. /

There was only a portion < of what was needed $>$ for them to eat together . . ․․ but there was nowhere from which the quantity needed for existence could come. Compulsion and force were the tidings, when he $\underline{3}$ was seated <in authority>; compulsion was the tidings, compulsion by misery; it came during his reign, when he arrived to sit upon the mat ... 2 Suddenly on high fire flamed up. The face of the sun was snatched away, ${ }_{4}$ taken from earth. This was his garment in his reign. This was the reason for mourning his power, at that time there was too much vigor. At that time there was the riddle for the rulers. $\underline{5}$ The planted timber was set up. Perishable things are assembled at that time. $\underline{\underline{6}}$ The timber of the grave-digger is set up at the crossroads, at the four resting places. $\underline{\underline{ }} \mathrm{Sad}$ is the general havoc, $\underline{\varepsilon}$ at that time the butterflies swarmed. Then there came great misery, when it came about that the sun in Katun 3 Ahau was moved from its place for three months. After three years $\underline{g}$ it will come back into place in Katun 3 Ahau. Then another katun will beset $<$ in its place $>$. The ramon 10 fruit is their bread, the ramon fruit is their drink; the jícama cimarrona ${ }_{11}$ is their bread, the jicama cimarrona is their drink; what they eat and what they drink. The ixbatun, 12 the

p. 104

chimchim-chay, 1 are what they eat. These things were present here when misery settled, father, in Tun 9. At that time there were the foreigners. The charge $<$ of misery $>$ was sought for all the years $\underline{2}$ of $<$ Katun $>13$ Ahau. $\underline{3}$

Then it was that the lord of <Katun $>11$ Ahau spread his feet apart. Then it was that the word of Bolon çacab ${ }_{4}$ descended to the tip of his tongue. Then the charge of the katun was sought; nine was its charge when it descended from heaven. Kan was the day when its burden was bound to it. $\underline{5}$ Then the water descended, it came from the heart of the sky for the baptism $\underline{\underline{6}}$ of the House of Nine Bushes. With it

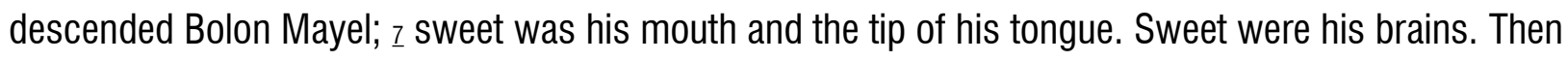
descended the four mighty supernatural jars, this was the honey of the flowers. $\underline{8}$ / Then there grew up for it the red unfolded calyx, g the white unfolded calyx, the black unfolded calyx and the yellow unfolded p. $46 \mathrm{C}$ calyx, those which were half a palm <broad $>$ and those which were a whole palm $<$ in

breadth $>$. Then there sprang up the five-leafed 10 flower, the five drooping $<$ petals $>$, the cacao $<$ with grains like $>$ a row of teeth, the ix-chabil-tok, the little flower, ${ }_{11}$ Ix Macuil Xuchit, 12 the flower with the brightly colored $\underline{13}$ tip, the laurel 14 flower, and the limping flower. 15 After these flowers sprang up, there were the vendors

p. 105

of fragrant odors, 1 there was the mother $\underline{2}$ of the flowers. Then there sprang up the bouquet of the priest, the bouquet of the ruler, the bouquet of the captain; this was what the flower-king bore when he descended and nothing else, so they say. $\underline{3}$ It was not bread that he bore. Then it was that the flower sprang up, wide open, to introduce the sin of Bolon-ti-ku. <After > three years was the time when he said he did not come to create Bolon çacab as the god in hell. Then descended Ppizlimtec ${ }_{4}$ to take the flower; $\underline{5}$ he took the figure of a 
humming-bird with green plumage on its breast, when he descended. Then he sucked the honey from the flower with nine petals. Then the five-petaled flower took him for her husband, $\underline{6}$ Thereupon the heart of the flower came forth to set itself in motion. Four-fold $\underline{\underline{z}}$ was the plate of the flower, and Ah Kin Xocbiltun $\underline{\underline{\varepsilon}}$ was set in the center. At this time Oxlahun-ti-ku came forth, but he did not know of the descent of the sin of the mat, when he came into his power. The flower g was his mat, the flower was his chair. He sat in envy, he walked in envy. Envy was his plate, envy was his cup. There was envy in his heart, in his understanding, in his thought and in his speech. Ribald and insolent was his speech during his reign. At that time his food cries out, his drink cries out, 10 from the corner of his mouth when he eats, from the back of his claw 11 when he bites his food. He holds in his hand a piece of wood, 12 he holds in his hand a stone. Mighty 13 are his teeth; his face is that of Lahun Chan, 14 as he sits. Sin is <in > his face, in his speech, in his talk, in his understanding < and in $>$ his walk. His eyes are blindfolded. ${ }_{15} \mathrm{He}$ p. 106

seizes, he demands as his right, 1 the mat on which he sits / during his reign. Forgotten is his father, forgotten is his mother, nor does his mother know her offspring. The heart is on fire alone in the fatherless p. $47 \mathrm{C}$ one who despises his father, in the motherless one. He shall walk abroad giving the appearance of one drunk, without understanding, in company with his father, in company with his mother. There is no virtue in him, there is no goodness in his heart, only a little on the tip of his tongue. He does not know in what manner his end is to come; nor does he know what will be the end of his reign, when the period of his power shall terminate.

${ }_{2}$ This is Bolon-ti-ku. < Like that of $>$ Bolon Chan ${ }_{\underline{3}}$ is the face of the ruler of men, the two day occupant of the mat and throne. He came in Katun 3 Ahau. After that there will be another lord of the land who will establish the law 4 of another katun, after the law of the lord of Katun 3 Ahau shall have run its course. At that time there shall be few children; then there shall be mourning among the Itza who speak our language brokenly. $\underline{\underline{5}}$ Industry $\underline{6}<$ and $>$ vigor finally take the place, in the first tun <of the new katun $>$, of the sin of the Itzá who speak our language brokenly. It is Bolon-ti-ku who shall come to his end $<$ with $>$ the law of the lord of Katun 3 Ahau. Then the riddle of the rulers of the land shall end the law of the katun. Then those of the lineage of the noble chiefs shall come into their own, $\underline{z}$ with the other men of discretion and with those of the lineage of the chiefs. Their faces had been trampled on the ground, and they had been overthrown by the unrestrained upstarts of the day and of the katun, the son of evil and the offspring of the harlot, who were born when their day dawned in Katun 3 Ahau. Thus shall end the power of those who are two-faced toward our Lord God.

But when the law of the katun shall have run its course, then God will bring about a great deluge again which will be the end of the world. When

p. 107

this is over, then our Lord Jesus Christ shall descend over the valley of Jehoshaphat beside the town of Jerusalem / where he redeemed us with his holy blood. He shall descend on a great cloud to bear true testimony that he was once obliged to suffer, stretched out on a cross of wood. Then shall 
descend in his great power and glory the true God who created heaven and earth and everything on earth. He shall descend to level off the world for the good and the bad, the conquerors <and > the captives. 1

\section{Footnotes}

98:2 Here we have a creation narrative of the sort described by Aguilar in his report on idolatry in Yucatan written early in the Seventeenth Century. "Furthermore it would be very advantageous if books were printed in the language of these Indians which would treat of Genesis and the creation of the world, because they have fables and histories which are very detrimental. Some of them have had them written down, and they keep them and read them in their assemblies. I had a copybook of this sort, which I took away from a choir-master named Cuytun from the town of Sucopo. He got away from me, and I never could get hold of him to learn the origin of this Genesis of his" (Aguilar 1900, p. 115).

98:3 This expresses admirably the religious attitude of the Maya who seem capable of superimposing Christianity on their old faith. See Appendix G.

98:4 See p. 95, note $\underline{2}$.

98:5 Maya, pay bentzil, employed as a synonym for tibil in Crónica de Oxkutzcab (Gates reproduction, Plates 161 and 166).

98:6 These may be what Avendaño refers to when he tells of the "devil" and "the worship which they (the Itzá) pay to him in the form of some stones" (Means 1917, p. 141. Cf. Appendix D).

99:1 Parallel versions of this passage occur in the Mani (p. 161) and the Tizimin (p. 20) MSS. Juan Martinez H. (1913, pp. 164-171) has made an excellent translation of the first part of this narrative, and suggests that the accompanying head of the "lord" of the katun is blurred in order to indicate that he is blindfolded.

99:2 Ah Mucencab: See p. 64, note 4.

99:3 Oxlahun-ti-ku, literally the Thirteen Gods, are probably the gods of the thirteen heavens of the Maya cosmos, but they are usually treated as a single god.

99:4 Bolon-ti-ku, or Nine Gods, appear to be treated as one god. We find them represented in the inscriptions, and it seems likely that they represent the nine underworlds and correspond to the Nine Lords of the Night of the Mexicans. (Cf. J. E. Thompson 1929, p. 225, and Seler 1923, p. 31.)

99:5 Cf. Motul, p. 346: "Eman u che u tunich Dios coklal: The punishment of God has come upon us with deaths or pestilence."

99:6 Cf. p. 67 , note $\underline{5}$.

99:7 Maya idol-makers removed the smut from their faces as a sign that their period of fast and consecration was over (Landa 1929, p. 70).

99:8 We have a Maya homonym here, and possibly quetzal plumage is meant by ix kukil ix yaxum. 
99:9 The seeds of the unidentified striped squash called ca.

99:10 Lit. nine generations, or eternal. According to Landa (1929, p. 20), Bolon çacab was set up in the house of the chief as a sort of tutelary god of the Kan years. He appears to be closely associated with the rain-god, Chac, and is identified by Seler as the god usually designated by the letter K. Seler 1902, p. 377. We are reminded of the Mexican image of Tlaloc composed of seeds.

99:11 Lit. "the 13th layer of the sky."

99:12 "pierced through:" The Tizimin and Mani versions say: "fell to pieces," (hutlahi).

99:13 See p. 67 , note $\underline{5}$.

100:1 Like the Mexicans, the Maya believed that the present order was preceded by other worlds which had been destroyed. According to the former, the fourth of these worlds, or "Suns," was destroyed by a great flood of water (Seler 1923, p. 40).

100:2 Supplied from the Tizimin and Mani versions. This was the red imix-tree which was set up in the east, for the Kan-xib-yuy, or Kan-xib-yuyum, to sit upon. (Cf. Mani MS. p. 162.)

100:3 Supplied from the Tizimin and Mani versions of this narrative.

100:4 Piçoy is spelled three ways in the three versions. The context leaves little doubt that a bird is meant. It may have been something like the mut, an unidentified bird of the Cracidæ family (Cf. Maler 1908, p. 132).

100:5 We find a portrayal of four trees, each surmounted by a bird, in one of the reliefs of the Temple of the Wall Panels at Chichen Itzá. (Cf. Plate 1, c.) Also on page 1 of the Codex Fejérváry-Mayer there is a Mexican picture of the four world-quarters at each of which there is a flowering tree with a bird perched upon it (Apud Seler 1923, p. 15). The yax-che or green tree at the center of the world is probably shown on pages 41-42 of the Maya Codex Cortesianus. This last tree is still remembered by the Maya (Cf. Tozzer 1907, p. 154). In the Ritual of the Four World Quarters found in Chapter I of the present work, these imix-trees, or trees of abundance, are further qualified as being the ceiba tree so prominent in Maya mythology (Cf. p. 64, note ${ }^{5}$ ).

101:1 Mention of the "plate" and "cup" of the katun is found several times in the Books of Chilam Balam. it is probably a reference to the ceremonies connected with the so-called idol of the katun (Cf. Landa 1929, p. 98). These articles appear to symbolize the numerical coefficient of the day Ahau from which the katun took its name. On page 150 it is said of Katun 9 Ahau: "Nine was its plate, nine was its cup."

101:2 Lahun Chaan is doubtless the same as the "Lakunchan" described by Cogolludo as an idol with very ugly teeth. Lahun means ten in both Maya and Chol, and chan means sky, heaven and serpent in Chol. The Maya word for sky is caan. It seems likely that Lahun Chaan is a borrowed foreign word and means the god of the tenth heaven. On page 47 of the Dresden Codex we find a picture (fig. 24) accompanied by a glyph composed of the number ten and an element which is generally accepted as the symbol of the sky or heavens. The picture is that of a deity whose face resembles that of the God B, or rain-god; but it lacks the curved ornament over the nose, and instead of the protruding tooth at the side of the mouth there is a fleshless lower jaw. Also skeleton-like ribs are painted on the front of the torso. We recall that a fleshless 
jawbone is one of the symbols of the number ten on the monuments; but the figure appears to be the regent of the second Venus period in the Dresden Codex, and the regent of the first of these periods in the Mexican Codex Bologna also has a fleshless lower jaw. Since the above passage in the Chumayel implies that Lahun Chaan was set in the west, the translator is inclined to believe that this god was closely connected with the appearance of Venus as an evening star. Cogolludo's mention of the "ugly teeth" may be a reference to the fleshless lower jaw in the picture (Cf. Cogolludo Bk. 4, Chap. 8).

101:3 Ah Uuc Chek-nal: he who fertilizes the maize seven times.

101:4 Itzam-kab-ain: literally, the whale with the feet of a crocodile. Martinez 1913, reprint p. 5. Beltran spells it Itzam-cab-ain, and defines it simply as whale, though it could mean literally Itzam-the-earth-crocodile. In either case, we are forcibly reminded of the fabled earth-monster which appears in the Dresden Codex (pp. 4 and 5) with the head of Itzamná between its jaws.

The Mexicans believed that the gods created "in the water a great fish, which is called cipáctli and which is like a crocodile, and from this fish they made the earth" (Hist. de los Mexicanos por sus pinturas, Chap. 2). On page 27 of the Codex Borgia we see this earth-monster with the head and claws of a crocodile and with maize sprouting from its back (Seler 1923, pp. 10, 11).

101:5 A change of one letter (tu muk to tamuk) would give to this sentence the meaning: then he descended while the heavens rubbed against the earth.

101:6 Maya, can cib, literally four wax candles. Cib is also the word for beeswax, but we find no record of candles being used prior to the Spanish conquest. The Maya employed torches of pitch-pine (tahté) or of the Viguiera dentata HBK (tah) for lighting. Thompson believes, however, that wax was used by the Maya for ceremonial purposes before the Conquest (J. E. Thompson, 1930, p. 105).

102:1 çac, here translated as series, also means degrees, steps, stairs and other things which go above one another. Motul.

102:2 The yax-cheel-cab, or first tree of the world is believed to be a giant ceiba which grows in the exact center of the earth and rears its branches through successive holes in the various heavens (Tozzer 1907, p. 154). Avendaño describes the representation of this mythological tree as "the fragment of a column, of round stone, the circumference of each part of which is about three quarters of a yard across and one quarter high. It is made of stones placed on top of each other with mortar of lime and cah cab (zahcab), which is usually used for that purpose; and the middle is filled in with bitumen, so that it is like a table with a round pedestal, upon which and set in the foundation of the said stone column, there stands out toward the West a stone mask, very ill-formed ... The said column is called, in the name by which they worship it, Yax cheel cab, which means in their language, 'the first tree in the world,' and, as it is understood in their old songs (which few people understand) they wish to have it known they worship it because it was the tree of whose fruit our first father Adam ate, who in their language is called Ixanom" (Means 1917, p. 135).

102:3 Cf. p. 157, note 2 . 
102:4 Cf. p. 72, note 13 .

102:5 Maya: çut polbil. çut means pointed like a hat. (Dict. San Francisco.) Polbil is defined as either rounded or shaped. The description fits the representations of the death-god in the Dresden Codex. (Pp. 10, $11,12,13$ and 19.) As ruler of the ninth and deepest hell, he sits upon the mat, the symbol of authority, and comprises in himself the idea of the gods of the nine under-worlds. Cf. Codex Vaticanus No. 3738, f. I v. apud Seler 1923, p. 21.

102:6 Probably the bases or pedestals on which the following deities were set.

102:7 Written ah ten pop ah ten çam in our text, but in the Mani and Tizimin MSS., ah tem pop ah tem cam. Tem is an altar or bench, and in compounds something set above something else. Tem is also a verbal stem meaning to alleviate. The mat (pop) and throne (cam) have the figurative significance of toil, misery and misfortune. (Motul, 1930, p. 694.) Consequently the expression could also mean "he who alleviates misfortunes." Cf. Tizimin, pp. 7, 8 and 25; Codex Perez, pp. 78, 82, 83, 107, 108, 153 and 161.

102:8 The Red, White, Black and Yellow "Rulers" appear to be the four gods who presided at the four cardinal points. Each is qualified by the adjective, tenel, which we believe to mean "raised up." It is probably an obsolete word, and we find temal substituted for it in the Mani MS. (Codex Perez, p. 116.) A discussion of the gods of the cardinal points will be found in Appendix A.

103:1 Maya, tu than. An expression often found in the medical manuscripts, meaning "so people say" or "so they call it," referring to various names applied to the same disease. Cf. Roys 1931, p. 16.

103:2 Lacuna in the text

103:3 Referring to Bolon-ti-ku.

103:4 Maya, colop, translated as though it were colob.

103:5 A reference to the interrogation of the chiefs. Cf. Chapter IX.

103:6 Maya, zatay babalil. This has been translated as it stands, but in connection with the "riddle for the rulers" we suspect that zatay batabil is intended. This would mean that the chiefs who are about to perish are assembled. Cf. Chapter IX.

103:7 This expression, to ho $<1>$ can be, tu ho $<1>$ can heleb, has been corrected from page 166 of the Kaua MS. Literally it means the four openings where two roads cross, the openings between the four resting places, i.e. the four corners at the cross-roads where travelers set down their packs and rested. Such would be a convenient place for an ambuscade, and here the slain would be buried. Ah muuc, here translated as gravedigger, means anyone who buries or conceals anything.

103:8 Maya, bul cum, might mean "all down" literally. Its translation here is based on the contexts in which it occurs. Always it is sad and to be mourned. On page 91 of the previous chapter it occurs in the courtyards of the nobles on an occasion when a number of chiefs are killed for failing to pass the test. Here it occurs at the cross-roads. In the prophecy for Katun 1 Ahau we shall find it closely associated with the flies (swarming on 
the corpses?) and mentioned in the same category with pestilence, famine and sudden death. It is an archaic expression and does not occur in any of the old dictionaries.

103:9 Lit. "three heaps of years." The translation of this sentence is uncertain.

103:10 The fruit of the ramon (Brosimum alicastrum Sw.) is boiled and eaten alone or with honey or cornmeal, and a sort of bread is made of the ground seeds.

103:11 The root of the Jícama cimarrona (Calopogonium cæruleum, Benth.) is eaten in time of famine. Dicc. San Francisco.

103:12 Ix-batun, or batun, is probably an unidentified wild plant or tree. Batun is a common family name among the Maya.

104:1 Chinchin-chay, a very spiny variety of Jatropha aconitifolia Mill., is boiled like cabbages and eaten when the corn crop fails (Relaciones de Yucatan, 1, p. 299).

104:2 A record of the misfortunes of each of the twenty years of a certain Katun 5 Ahau is found in the Tizimin (pp. 1-13) and Mani (pp. 135-156) manuscripts.

104:3 Most of the preceding paragraph concerning Katun 3 Ahau appears to be an interpolation. It is not found in the Tizimin and Mani versions.

104:4 Bolon çacab: Cf. p. 99, note 10.

104:5 Cf. Stela D, Copan (apud Morley 1915, PI. 14) where the personified numeral is the bearer and the time-period is the burden.

104:6 Alternative translation: for the rebirth etc.

104:7 Bolon Mayel means "the fragrant one."

104:8 For this sentence the following is substituted in the Mani and Tizimin versions of this narrative: "Then descended two mighty demon bats who sucked the honey of the flowers."

104:9 Unfolded calyx (hoch kom): hoch has a number of different meanings, but in the Tizimin and Mani versions choch is substituted, which is a synonym for hoch in the sense of "to untie, to unfold." Kommeans something bent, curved or hollowed out in general, and a socket or a depression in the earth in particular. Kom lac is a deep plate. In view of the context here, the calyx of a flower seems to be meant.

104:10 Maya, ix-ho-yal. Ho means five, and, yal, after a numeral, means thin layers, folds or sheets. Literally this would mean five circles of floral leaves composing the perianth. This seems unusual, and it is probable that five leaves are meant.

104:11 I $x$-bac nicte: ix-bac means a little girl, and there may be a plant of that name, as it is also a placename. Nicte means flower in general, particularly the Plumeria.

104:12 Macuil Xochitl is Nahuatl for Five Flower, the Mexican god of music and dancing, probably introduced into Yucatan by the Toltecs. 
104:13 Alternative translation: hollow tip.

104:14 Laul: Stemmadenia insignis Miers., much admired by the Maya (Landa 1900, p. 386).

104:15 In the Maya treatises on medical plants this word, nicté, always designates the Plumeria, but here the definition found in all the Maya dictionaries has been followed: "Nicté. A rose, or a flower, not indicating from what tree, bush or plant." Motul. A secondary meaning is: "Nicté. Deshonestidad, vicio de carne y travezuras de mugeres."

105:1 Possibly the pollen-bearing insects and humming-birds are meant here. We find a masculine prefix. 105:2 In the Tizimin and Mani versions we find: "there was the house of the flowers."

105:3 Alternative translation: there was no other food than this, so they say.

105:4 "Although they had a god of song whom they called Xocbi<l>tum, they worshipped the idol, the statue of an Indian who, they said, was a great singer and musician named Ah Kin Xooc. They adored him as the god of poetry and also called him Pizlimtec." Cogolludo Bk. 4, chap. 8.

105:5 Alternative translation: to the root of the flower.

105:6 The five-petaled flower, or nicté, is without doubt the Plumeria. The red Plumeria and the white Plumeria are considered the father and mother respectively of Nohochacyum, the head of the Lacandon Pantheon (Tozzer 1907, p. 93).

105:7 Maya, can-hek: literally, four-branched.

105:8 See note 4 .

105:9 Here the flower, probably a Plumeria, is closely associated with the idea of carnal sin. Cf. p. 104, note 15.

105:10 "his food cries out, his drink cries out:" here the Mani and Tizimin versions of the narrative have been followed in the translation.

105:11 Xau, translated here as claw, also means the toes of a man.

105:12 Alternative translation: He holds in his hand a tree.

105:13 Alternative translation: Great is his madness.

105:14 Lahun Chan: see p. 101, note 2.

105:15 A blindfolded god is pictured on page 50 of the Dresden Codex, and the blurred faces of the Lords of the Katuns on page $\underline{144}$ of the Chumayel are believed to represent the same thing.

106:1 "He seizes, he demands as his right the mat," etc.: here the Mani and Tizimin versions have been followed, as indicated in the Maya text. 
106:2 As on page 103, we have here another interpolation which also treats of the interrogation of the chiefs in Katun 3 Ahau. Cf. p. 89.

106:3 It seems likely that the Maya compiler has inadvertently written Bolon Chan for Lahun

Chan. Bolon means nine, and lahun means ten. No personage by the name of Bolon Chan is known to the translator, while Lahun Chan is well known. See p. 101, note 2 .

106:4 The than of the katun is translated as its "law," following the explanation on page 171 of the Kaua MS., where it is defined as "ordenanzas." The expression recurs so frequently in this book that an explanation seems to be required. Primarily than means word, speech or language, but it also has a number of different meanings when employed figuratively. If it were not for this definition in the same context in the Kaua MS., we should be inclined to translate it as "the force, power and duration" of the katun. See Motul 1930, p. 875.

106:5 "Nun, or ah nun: A stupid foreigner who does not know the language of the country, or a stammerer or a stutterer; also a stupid person whom it is of no use to teach" (Motul 1930, p. 695).

106:6 Maya, chuen. The translation is based on the word, ah-chuen, defined as artisan (Motul).

106:7 Possible alternative translation: Then those of the lineage of the noble chiefs shall appear. Cf. p. 92.

107:1 Possible alternative translation: the conqueror of the stupid ones. Cf. text, p. 34, note 1. 